\title{
Response of Mung Bean (Vigna radiata L. Wilczek) Varieties to the Application Rates of Phosphorus in Ambasel District, North-eastern Ethiopian Lowlands
}

\author{
Getachew Hussen ${ }^{1}$, Mekonnen Asrat ${ }^{2,}$, Ahadu Menzer ${ }^{2}$ \\ ${ }^{1}$ Ambasel District Trade Office, Wuchale, Ethiopia \\ ${ }^{2}$ Departement of Plant Sciences, Debre Markos University, Debre Markos, Ethiopia
}

Email address:

mek.asrat@yahoo.com (M. Asrat)

${ }^{*}$ Corresponding author

To cite this article:

Getachew Hussen, Mekonnen Asrat, Ahadu Menzer. Response of Mung Bean (Vigna radiata L. Wilczek) Varieties to the Application Rates of Phosphorus in Ambasel District, North-eastern Ethiopian Lowlands. American Journal of Plant Biology. Vol. 5, No. 4, 2020 , pp. 88-98. doi: 10.11648/j.ajpb.20200504.13

Received: May 21, 2020; Accepted: August 24, 2020; Published: November 23, 2020

\begin{abstract}
Phosphorus fertilizers have a great importance for mung bean (Vigna radiata). It not only increases the yield and yield components of the crop but also improve the quality of the produce. This experiment was designed to evaluate the performance of phosphorus application rates on different mung bean varieties. The experiment was conducted at Robbitkebele in Ambasel district on the land of fruit development and seedling nursery of Amhara Development Association (ADA). It was carried out under rain fed conation of 2016 main season. The effects of $\mathrm{P}$ application rate on yield and yield components of the crop were studied using three varieties (N26, $\mathrm{NVL}^{-1}$ and Shewarobit). The varieties were received four levels of phosphorus $(0$, 23, 46and $69 \mathrm{~kg} \mathrm{ha}^{-1} \mathrm{P}_{2} \mathrm{O}_{5}$ ) with factorial randomized complete block design (RCBD) and the treatments replicated three times. The results showed that application of $\mathrm{P}$ significantly affected total mung bean yield. Main effects of crop varieties and phosphorus rate were showed significant influence on thedays to flowering, days to maturity, plant height, number of pods per plant, number of seeds per pod, harvest index, biomass yield, and seed weight per plant. However, days to emergence, stand count at emergence, and stand count at harvest were not significantly affected by individual effects of crop variety and $\mathrm{P}$ rate. The maximum plant height, number of seeds per pod and 100 seeds weight were obtained due to planting mung bean N26 variety. The maximum weight of seeds per plant, number of pods per plant, biomass yield harvest index and grain yield were recorded by NVL 1 variety meanwhile the lowest grain yield obtained by Shewarobit variety. Mung bean N26 variety and 69 $\mathrm{kg} \mathrm{ha}^{-1} \mathrm{P}_{2} \mathrm{O}_{5}$ treatment produce the highest yield. Application of phosphorus up to $46 \mathrm{kgha}^{-1} \mathrm{P}_{2} \mathrm{O}_{5}$ increased number of pods per plant, pod length, number of seeds per pod, seed yield, harvest index, biomass yield, yield and 100 seed weight in a rapid change but application of more dose of phosphorus increase the yield at low rate. Based on the economic analysis application of $46 \mathrm{~kg} \mathrm{ha}^{-1} \mathrm{P}$ for variety NVL1, and $69 \mathrm{~kg}$ P for N26 and Shewarobit varieties were economically feasible.
\end{abstract}

Keywords: Ambasel, Mung Bean, N26, NVL1 Variety, Phosphorus

\section{Introduction}

Mung bean (Vigna radiate L. Wilczek) is an important legume crop with high nutritive values. It is an eco-friendly food grain leguminous crop for dry land agriculture [1]. According to the nutritionists, pulses are an excellent source of dietary proteins and can play an important role in fulfilling food requirements of rapidly increasing population [2]. Growth of human population from 6.1 billion in mid 2001 to
9.3 billion by 2050 should be in par with crop production to ensure food security [2]. Mung bean seed is more palatable, nutritive, digestible and non-flatulent than other pulses grown in country. It is also known as king of the pulses. Mung bean contains $1-3 \%$ fats, $50.4 \%$ Carbohydrates, $3.5-4.5 \%$ fibers and 5.5\% ash, while calcium and phosphorus are 132 and 367 mg per 100 grams of seed, respectively [3, 4 and 5]. Pulses 
contain important amino acids known as lysine which is frequently available in mung bean crop but deficient in most of cereal grains and therefore known as poor man meat [5]. Besides, being a rich source of protein, it maintains soil fertility through biological nitrogen fixation in soil and thus plays a vital role in furthering sustainable agriculture [6]. The crop is a short duration crop therefore has less water requirement as compared to summer crops. Moreover, it is drought resistant that can withstand adverse environmental conditions, and hence successfully be grown in rain fed areas [7].

Phosphorus effect on root establishment and development is well known [8]. Phosphorus is one of the three macronutrients that plants must obtain from the soil. It is a major component of compounds whose functions relate to growth, root development, flowering, and ripening [9]. Addition of $\mathrm{N}$ and $\mathrm{P}$ fertilizer enhances root development, which improves the supply of other nutrients and water to the growing parts of the plants, resulting in an increased photosynthetic area and thereby more dry matter accumulation [9].

Inadequate nutrient status of soil is a particular problem for small landholder farmers of the developing countries, where much grain-legume production couldn't apply that mach [10]. Introduction of high yielding varieties and increased cropping intensity requires heavy applications of $\mathrm{N}$ and $\mathrm{P}$ fertilizers. As in [11] disclosed the yield of different crops have been noticed from the soil application of the deficient macronutrient, therefore the poor availability of phosphorus fertilizer is one of the major causes depressing the productivity of the crops. On the other hand, soil $\mathrm{P}$ fixation depends on method of application, $\mathrm{P}$ broadcasting expose for fixation than band application since broadcast application has create more contact ratio between the fertilizer and soil mean while and application narrowing the contact ratio between $\mathrm{P}$ and soil [12].

Farmers have a wrong notion that mung bean, being legume crop does not need any nutrient and usually grow it on the marginal lands without applying any fertilizer. This seems to be an important reason for low productivity in the country. In contrary many authors disclosed that, $\mathrm{P}$ application on leguminous crop improves yield components and yield of green gram straw yield, number of branches, number of pods plant ${ }^{-1}$, number of seeds $\operatorname{pod}^{-1}$ and 1000grain weight considerably as compared with treatments given no phosphorus [13, 14]. As well as adequate amount of phosphorus in soils favors' rapid plant growth, early fruiting and maturity and improves the quality of the produce. However meager information on $\mathrm{P}$ application rate hinders the improvement of the crop yield in north Eastern Ethiopia in general and in the study area in particular.

Therefore, this study was designed with the following specific objectives

To investigate the effect of $\mathrm{P}$ application rates on phenological stages, growth and yield components of the crop.

To determine the optimum rate of $\mathrm{P}$ for different varieties of mung bean

\section{Materials and Methods}

\subsection{Description of the Study Area}

The experiment was conducted at Robbitkebele in Ambasel district on the land of fruit development and seedling nursery of Amhara Development Association (ADA) (Figure 1). This site is located at $450 \mathrm{~km}$ north-east of Addis Ababa in south Wollo administrative zone of Amhara National Regional State. The area has been received an average rainfall of $800 \mathrm{~mm}$ in annual with mean average minimum and maximum temperatures of 15 and $20^{\circ} \mathrm{C}$, respectively. This site is situated at an altitude of 1531 meters above sea level. The soil type of the site is sandy clay loam.

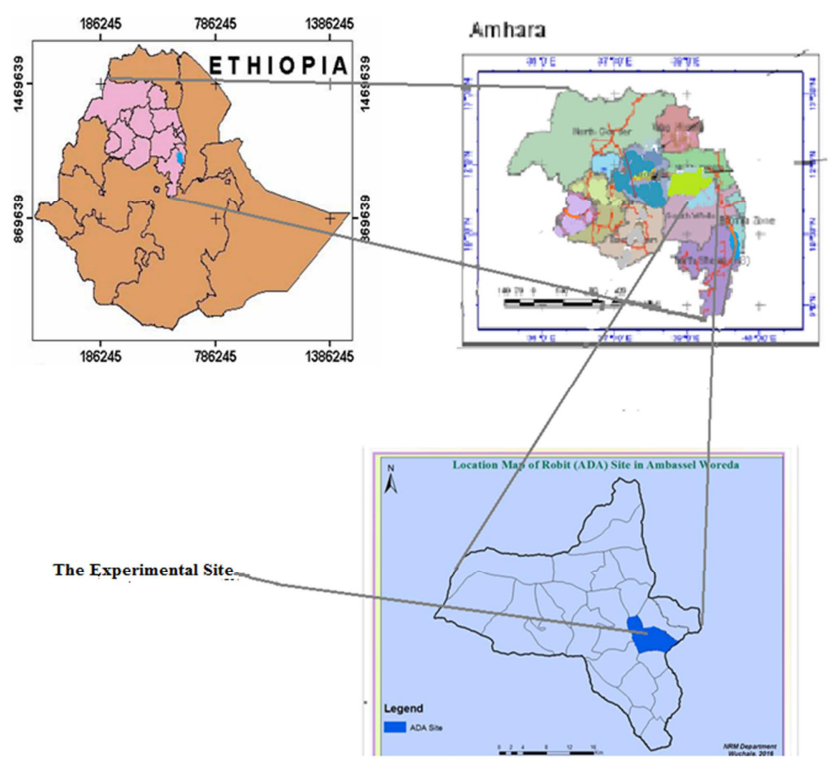

Figure 1. Location map of the experimental site.

\subsection{Experimental Materials}

Two mung bean varieties (N26 and NVL 1) were collected from Melkasa Agricultural Research Centre while Shewarobit variety collected from local area for this experiment. Nitrogen fertilizer as of urea and phosphorus fertilizer as of TSP were used in the study. Uniform rate of $11.5 \mathrm{~kg} / \mathrm{ha} \mathrm{N}$ fertilizer was applied for all experimental plots.

\subsection{Treatments and Experimental Design}

These experimental treatments were arranged through factorial combinations of three mung bean varieties (N26, NVL/1, and Shewarobit) and four levels of $\mathrm{P}(0,23,46$ and 69 $\mathrm{kg} \mathrm{ha}^{-1} \mathrm{P}_{2} \mathrm{O}_{5}$ ) (Table 1). The treatments were replicated three times and laid out in randomized complete block design (RCBD). Each experimental plot size was $2.5 \mathrm{~m}$ long and 2.0 $\mathrm{m}$ width (area of $5 \mathrm{~m}^{2}$ ), the crop planted on row by leaving 20 $\mathrm{cm}$ from both sides of gross plot size. The net area of each plot was considered by leaving one outermost row on both sides of inter row spacing while two outermost rows on both sides of intra row of the plot. Therefore, the net plot has an area of 1.6 $\mathrm{x} 2.1 \mathrm{~m}\left(3.36 \mathrm{~m}^{2}\right)$. Each block was separated by a space of $1 \mathrm{~m}$ meanwhile each plots separated with a distance of $0.5 \mathrm{~m}$. 
Phosphorus fertilizer was applied in band just at time of planting while $11.5 \mathrm{~kg} /$ ha nitrogen applied as a starter. The crop was planted on row at 250,000 plants/ha seed rate with intra and enter row space of 10 and $40 \mathrm{~cm}$, respectively. Furthermore, all recommended cultural practices that adopted for mung bean production properly implemented in this experiment for all plots, simultaneously.

\subsection{Data Collection}

Plant growth data such as plant height and number of pods per plant were recorded from randomly selected 10 plants on net plot area. Moreover, crop yield data such as grain, biomass and 100 seeds weights and harvest index were measured from the yield obtained on net plot area. Plant height was measured from the ground level to the top of the plant at flowering and at physiological maturity from 10 randomly selected plants from each plot. Number of pods per plant is determined as the total number of pods in each plant and it was recorded after pod formation and at physiological maturity (when pods matured and dried but before they start shattering). Number of seeds per pod was determined as the total number of seeds per pod on selected plant recorded at maturity. The dry weight was measured from 10 randomly taken mature plants seed from each plot after oven drying at $70^{\circ} \mathrm{C}$ until maintain constant weight. Harvest index was computed as the ratio of mature seed yield per plant to the total biomass.

One hundred seeds weight was measured by counting 100 seeds randomly collected from each treatments and measure by using a sensitive balance. All crop yields were converted into hectare basis. Biomass yield was determined during maturity the whole plant parts including steam leaves pods from the net plot area was measured after harvest and sun drying for three consecutive days.

\subsection{Soil Sampling and Analysis}

Ten soil samples were collected from the experimental field in zigzag fashion at plough depth $(0-25 \mathrm{~cm})$ before planting the crop. Then the samples thoroughly mixed and formed a composite sample to determine its physicochemical properties. After the crop harvest soil samples collected from each plot to determine the effect of treatment on selected chemical properties of the soil (organic carbon, total $\mathrm{N}$ and available P). The collected soil sample was air dried, grinded and sieved through a $2 \mathrm{~mm}$ sieve size to determine soil $\mathrm{pH}$, available $\mathrm{P}$, exchangeable potassium and electric conductivity of soil. While it was sieved in $0.5 \mathrm{~mm}$ diameter size to determine the organic carbon and total $\mathrm{N}$ content of the soil. Soil $\mathrm{pH}$ was determined by diluting the soil in a $0.01 \mathrm{M}$ $\mathrm{CaCl}_{2}$ solution in the ratio of soil salt of $1: 2.5$. Total nitrogen was determined by Kjeldahl method [15] while organic carbon estimated using the wet digestion method [16]. Available phosphorous content of the soil extracted with $0.5 \mathrm{M} \mathrm{NaHCO} 3$ [17] and measured by atomic absorption spectrophotometer following the procedure as outlined in [18]. Exchangeable potassium content of the soil was measured using flame photometry [19].

\subsection{Data Analysis}

The data were subject to analysis of variance as in [20] procedure using the latest version of SAS software [21]. Significant difference among treatment means was delineated by LSD procedure at $5 \%$ level of significance.

Economic analysis was conducted through CIMMYT partial budget methodology [22]. The total variable cost included the cost of $\mathrm{P}$ fertilizer and grain seed in a hectare base. The net benefit was calculated as the difference between the gross field benefit (birr per ha). The economic analysis was carried out by considering estimated prices of $\mathrm{P}$ fertilizer and mung bean grain during the application and harvesting season, respectively. The price of each $\mathrm{kg}, \mathrm{P}$ fertilizer and mung bean grain were 24.45 and 16.875 birr, respectively in local market area. While costs of weeding, harvesting (threshing and winnowing), packaging material and transporting were 1000 birr per ha, 80 birr per $100 \mathrm{~kg}, 7$ birr per $100 \mathrm{~kg}$ and 5 birr per $100 \mathrm{~kg}$, respectively.

\section{Results and Discussion}

\subsection{Selected Physicochemical Properties of the Experimental Soil}

The pre planting soil was sandy clay loam in texture and with 6.8 soil $\mathrm{pH}$; thus it was suitable for mung bean cultivation (Table 1). The experimental soil was found to be moderate in CEC (32.5 $\left.\mathrm{Cmolc}_{(+)} \mathrm{kg}^{-1}\right)$, non saline or low in salt content $(4 \mathrm{ds} / \mathrm{m})$, high in exchangeable potassium $(0.65$ cmolc $_{(+)} \mathrm{kg}^{-1}$ soil), low in total nitrogen $(0.18 \%)$ and also Available phosphorous of soil was high (13.4 $\left.\mathrm{mg} \mathrm{kg}^{-1}\right)$, according to Olsen $\mathrm{P}$ sufficiency test soil $\mathrm{P}$ is very low at $<3$ ppm, low at $4-7 \mathrm{ppm}$, medium $8^{-1} 1 \mathrm{ppm}$ and high $>12 \mathrm{ppm}$ [23]. As per [24] scaling the soil has high organic carbon content $(4.5 \%)$ or $7.74 \%$ organic matter.

Table 1. The pre-planting properties of experimental soil.

\begin{tabular}{lll}
\hline Soil physicochemical properties & Unit & Value \\
\hline Clay & $\%$ & 41.5 \\
Silt & $\%$ & 28.9 \\
Sand & $\%$ & 30.5 \\
Soil texture class & - & Sandy clay loam \\
Total nitrogen & $\%$ & 0.18 \\
Available phosphorus & $\mathrm{mg} \mathrm{kg}^{-1}$ & 13.4 \\
Exchangeable potassium & $\mathrm{Cmol}_{(+)} \mathrm{kg}^{-1}$ & 0.65 \\
Organic carbon & $\%$ & 4.5 \\
pH & - & 6.8 \\
EC & $\mathrm{mm} \mathrm{hos}^{-1}$ & $4 \mathrm{ds} / \mathrm{m}$ \\
Cation Exchange Capacity (CEC) & $\mathrm{Cmol}_{(+)} \mathrm{kg}^{-1}$ & 32.5 \\
\hline
\end{tabular}

\subsection{Effects of Residual Nutrients on Selected Chemical Properties of Soil}

The post harvest soil samples were collected from each plot and then composited per treatment for the analysis of total $\mathrm{N}$, available $\mathrm{P}$ and organic carbon. The analysis results indicated that maximum residual total $\mathrm{N}(0.2 \%)$ was obtained 
on mung bean N26 variety planted and $69 \mathrm{~kg} \mathrm{ha}^{-1} \mathrm{P}_{2} \mathrm{O}_{5}$ applied treatment. However, minimum residual total $\mathrm{N}$ was recorded on the local cultivar (Shewarobet) planted and $\mathrm{P}$ applied treatments (Table 2). Thus, improved variety removed lower $\mathrm{N}$ nutrient as compared to local variety, it might be due to more fixation capacity of an improved varieties as compare to local mung bean. Maximum residual organic matter content of post harvest soil (7.22\%) was recorded on minimum $\mathrm{P}$ application rate across all crop varieties. Meanwhile, minimum residual organic matter (6.9\%) observed on maximum $\mathrm{P}$ applied treatments. Thus an applied P nutrient increases decomposition of organic matter. Maximum residual $\mathrm{P}$ obtained on treatment that received more P fertilizers. Generally residual N and P nutrients were should positively related it might be due to synergetic effect of these nutrient (Table 2).

Table 2. Residual soil nutrient content of post harvest soil.

\begin{tabular}{llllll}
\hline No & Treatments & Total N (\%) & Avil. P(mg kg $\left.\mathbf{~}^{-1}\right)$ & OC (\%) & OM\% \\
\hline 1 & V1*0 & 0.189 & 12.8 & 4.2 & 7.24 \\
2 & V1*23 & 0.19 & 13.0 & 4.1 & 7.07 \\
3 & V1*46 & 0.192 & 13.2 & 4.1 & 7.07 \\
4 & V1*69 & 0.2 & 13.3 & 4.0 & 6.9 \\
5 & V2*0 & 0.19 & 12.9 & 4.1 & 7.07 \\
6 & V2*23 & 0.19 & 13.0 & 4.0 & 6.9 \\
7 & V2*46 & 0.196 & 13.2 & 4.0 & 6.9 \\
8 & V2*69 & 0.195 & 13.4 & 4.1 & 7.07 \\
9 & V3*0 & 0.185 & 13.0 & 4.2 & 7.24 \\
10 & V3*23 & 0.188 & 13.2 & 4.2 & 7.24 \\
11 & V3*46 & 0.19 & 13.2 & 4.1 & 7.07 \\
12 & V3*69 & 0.19 & 13.3 & 4.0 & 6.9 \\
Mean & & 0.191 & 13.12 & 4.09 & 7.05 \\
\hline
\end{tabular}

Whereas: V1, V2and $\mathrm{V}_{3}=\mathrm{N} 26$, NVL 1 and Shewarobit (local), respectively.

\subsection{Effects on Growth and Yield of the Crop}

Crop growth and yield responses were significantly affected by genetic make-up of the crop and different environmental factors such as light, temperature, soil nutrient and management practices. In this experiment most parameters of the crop phenological stage, growth and yield were significantly influenced by individual effects of crop variety and $\mathrm{P}$ application rate. Maximum number of seeds per pod, weight of seed per plant, harvest index, biomass yield, plant height and 100 seeds weight were obtained at $69 \mathrm{~kg}$ ha ${ }^{1} \mathrm{P}_{2} \mathrm{O}_{5}$ application rate. Grain yield of this $\mathrm{P}$ application rate increased by $1.63 \mathrm{t} / \mathrm{ha}$ over the control treatment. As in [25] report $\mathrm{P}$ application rates were significantly increased the growth of plants, number of nodules, dry matter production as well as mung bean grain yield as compared to the control plot. Phosphate fertilization has increasing influence in relation to growth and yield. Higher yields of mung bean have been obtained by application of $90 \mathrm{~kg} \mathrm{ha}^{-1}$ phosphorous under field conditions [26. 27]. Moreover, as in [28, 29] the effect of phosphorus rates on mung bean response indicated that application of $75 \mathrm{~kg} \mathrm{ha}^{-1} \mathrm{P}$ gave the highest grain yield $(1.83 \mathrm{t} / \mathrm{ha})$. On the other hand, the combined use of $\mathrm{P}$ and Rhizobium inoculation gave maximum 100 seeds weight, grain yield and protein content seed [30]. Contrary to this finding [31] report indicated that a factorial combination of three levels of nitrogen and three levels of phosphate fertilizer on mung bean and independent responses to phosphate was reported.

\subsection{Growth Paraeters}

\subsubsection{Stand count at Emergence (SCE) and Harvest (SCH)}

The analysis of variance for stand count at emergence and harvest revealed that no significant variations due to the main effect of the variety, however slight differences of stand count were recorded among mung bean varieties. The maximum number of count $\left(29.52 \mathrm{plant} / \mathrm{m}^{2}\right)$ registered by $\mathrm{N}$ 26 variety. Meanwhile, the minimum number (26.8 plants per $\mathrm{m}^{-2}$ ) was recorded by Shewarobit mung bean variety. Moreover, the stand count at harvest shows no significant result by the crop. Similarly, main effect of $\mathrm{P}$ application rate non-significantly influences stand count at the emergence and the harvest of the crop. The Combination effect of crop and phosphorus application rates showed no significant variation in respect of stand count at emergence and at harvest.

\subsubsection{Plant Height}

Plant height was influenced significantly by individual effect of crop variety but non-significantly affected by main effect of $\mathrm{P}$ and interaction effect of crop variety and $\mathrm{P}$ rate. N26 mung bean variety, gave the highest plant height (68.9 $\mathrm{cm})$ at harvest time. The shortest plant height of $62.4 \mathrm{~cm}$ was obtained in Shewarobit (local) variety. NVL1 variety also gave the medium plant height $(64.5 \mathrm{~cm})$. Probably the genetic makeup of the variety was responsible for the variation in plant height. Similar studies also revealed that plant height is increased by the age of plant and within the period of 40-50 DAS for different cultivars [32, 33, 34].

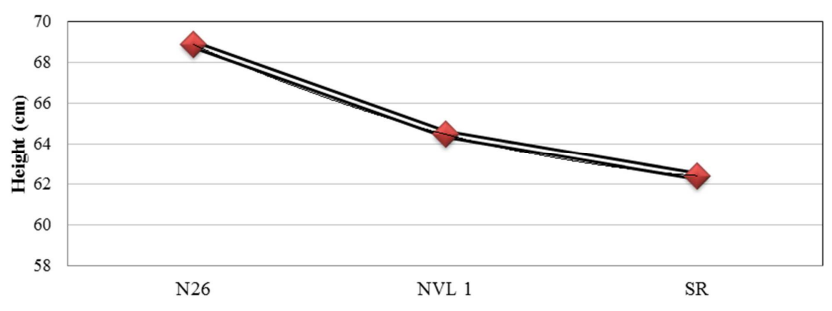

Figure 2. Main effect of crop variety on plant height of mung bean.

Phosphorus had a significant effect on plant height. The tallest plant height of $(66.6 \mathrm{~cm})$ was recorded by the application of $69 \mathrm{~kg} \mathrm{ha}^{-1} \mathrm{P}_{2} \mathrm{O}_{5}$ while the shortest plant height $(63.6 \mathrm{~cm})$ was found with control treatment (Figure 3). The increase in plant height under phosphorus treatment might be due to effect of phosphorus in metabolism of growing plants, in its growth yield, and yield parameters. The results are in agree with [35, 36] reports. As in [13] report phosphorus application showed significant influence on plant height with increasing levels of phosphorus application from 0 to $40 \mathrm{~kg}$ $\mathrm{ha}^{-1} \mathrm{P}_{2} \mathrm{O}_{5}$. In contrary to this, increasing $\mathrm{p}$ levels can decrease plant height [30]. 


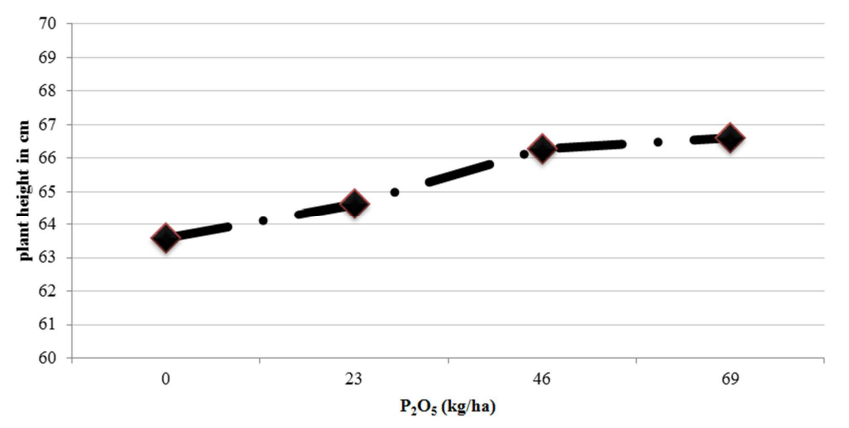

Figure 3. Effect of phosphorus rate on plant height.

\subsection{Yield and Yield Related Parameters}

\subsubsection{Number of Pods Per Plant}

Varieties were significant to the number of pods per plant. The highest number of pods per plant (33.1) was obtained by NVL1 variety. Meanwhile, the lowest number of pod per plant (31.2) recorded by Shewarobit variety (Figure 4). As in [37] report the variety has significant effect on number of pod per plant and number of pods of mung bean.

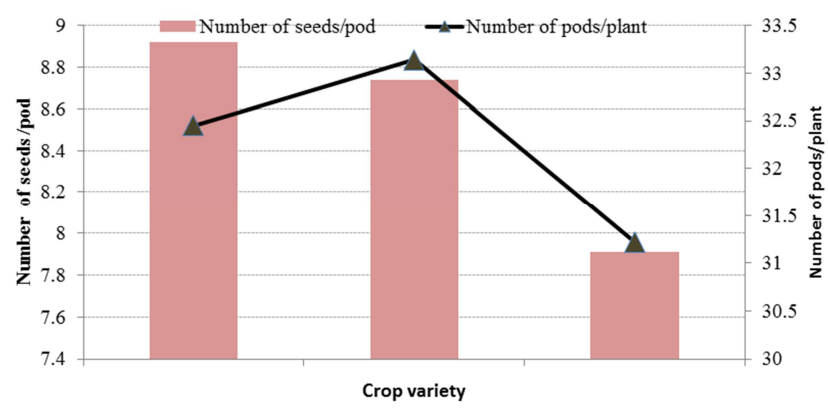

Figure 4. Effect of crop variety on number of pods per plant and number of seeds per pod.

Similarly, number of pods per plant was significantly affected by the application of phosphorus. However, the interaction effect of crop variety and $\mathrm{P}$ rate was not significantly affecting the number of pods per plant. The application of $46 \mathrm{~kg} \mathrm{ha}^{-1} \mathrm{P}_{2} \mathrm{O}_{5}$ produced the highest number of pods per plant (33.7). The second highest number of pods per plant (33.6) was produced at $69 \mathrm{~kg} \mathrm{ha}^{-1} \mathrm{P}_{2} \mathrm{O}_{5}$. The control treatment produced the lowest number of pods per plant (30.06). Increasing level of phosphorus up to $46 \mathrm{~kg} \mathrm{ha}^{-1} \mathrm{P}_{2} \mathrm{O}_{5}$ increased the number of pods per plant and then it decreased with excess $P$ rate (Figure 5). This result agrees with [38, 39] reports also. An application of 40 and $60 \mathrm{~kg} \mathrm{ha}^{-1} \mathrm{P}_{2} \mathrm{O}_{5}$, respectively increased the number of pods of mung bean [40] Besides, the greenhouse experiment on saline soil indicated that application of $\mathrm{N}$ and $\mathrm{P}$ increased pods number and grain yield of mung bean [41].

\section{Number of seeds per pod}

Main effect of crop variety showed significant influence on the number of seeds per pod. Hence; Individual effects of crop variety and $\mathrm{P}$ applications rate were showed significant influence on number of seeds per pod. The highest number of seeds per pod (8.9) was recorded by N26 variety, meanwhile the lowest (7.9) number of seeds per pod was obtained by Shewarobit mung bean (Figure 4). In line with to this different mung bean varieties were responded various number of seeds per pod [42].

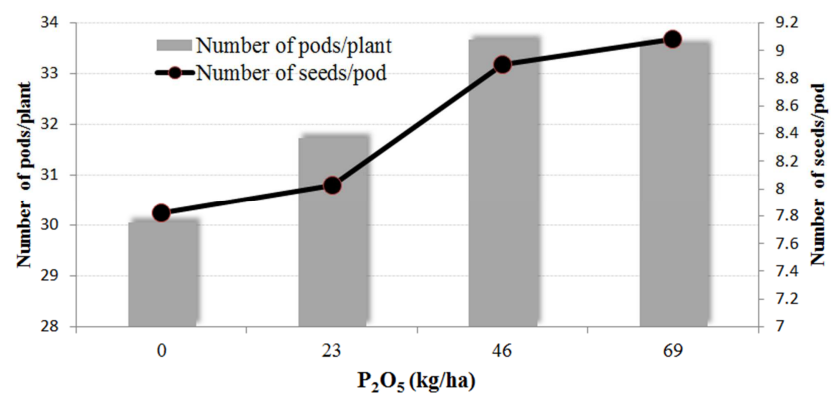

Figure 5. Effect of phosphorus rate on number of pods per plant and number of seeds per pod.

The treatments that received $69 \mathrm{~kg} \mathrm{ha}^{-1} \mathrm{P}_{2} \mathrm{O}_{5}$ produced highest number of seeds per pod. Meanwhile, the lowest seeds per pod were recorded with zero $\mathrm{P}$ level treatment across all crop varieties (Figure 5). Thus, $\mathrm{P}$ application has enhances seed set up of the crop. As in [30, 43] reports mung bean seed inoculation with Rhizobium and $70 \mathrm{~kg} \mathrm{ha}^{-1} \mathrm{P}_{2} \mathrm{O}_{5}$ applied treatment gave the highest (12) number of seeds per pod. Besides, field experiment conducted disclosed that an application of $40 \mathrm{~kg} \mathrm{ha}^{-1}$ phosphorus significantly increased the number of seeds per pod [44].

Weight of seeds per plant

Main effects of crop variety and $\mathrm{P}$ application rate significantly affect the weight of seeds but insignificantly affected by their interaction effect. The highest weight of each crop seeds (10.6 g) was recorded on NVL1 variety meanwhile the lowest weight of each crop's seeds (7.2 g) was obtained on Shewarobit variety (Figure 6). Similarly, six mung bean varieties were gave various weight grain yields from each plant [45].

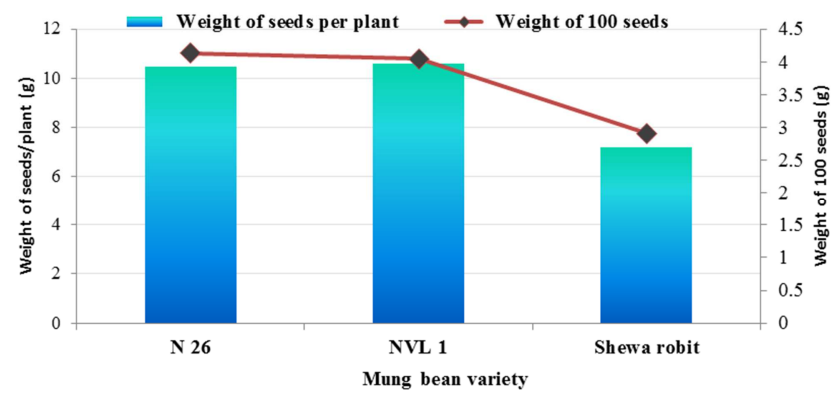

Figure 6. The influence of mung bean varieties on weight of seeds per plant and100 seeds.

On the other hand, the treatment that received $69 \mathrm{~kg} \mathrm{ha}^{-1}$ $\mathrm{P}_{2} \mathrm{O}_{5}$ was produced the highest weight of seeds per plant $(10.4 \mathrm{~g})$. But zero $\mathrm{P}$ treatment of all crop varieties responded the lowest $(7.9 \mathrm{~g})$ weight of seeds per plant. Similarly, an application of 40 and $60 \mathrm{~kg} \mathrm{ha}^{-1} \mathrm{P}_{2} \mathrm{O}_{5}$ were increased the weight of mung bean seeds over the control and low $\mathrm{P}$ application rate $\left(20 \mathrm{~kg} \mathrm{ha}^{-1}\right)$ [40].

The weight of hundred seeds 
The weight of 100 seeds was influenced by individual effects of crop variety and $\mathrm{P}$ application rate but their interaction effect has no significance influence on 100 seeds weight. The highest weight of 100 seeds $(4.1 \mathrm{~g})$ was recorded by N26 variety meanwhile the lowest weight of seed (2.92 g) was registered from Shewarobit mung bean variety (Figure 6). This finding is also supported by [37] report.

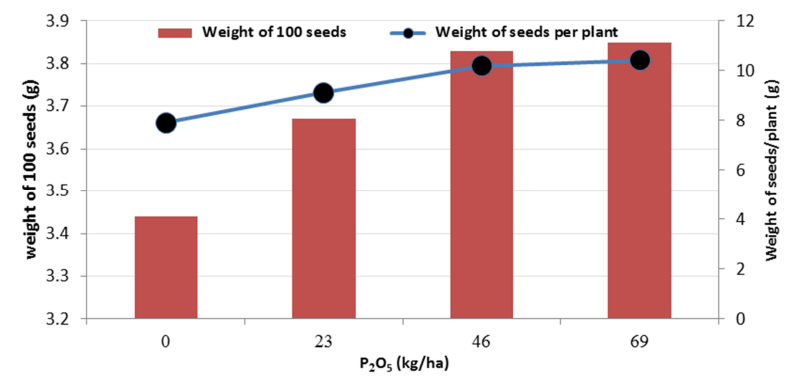

Figure 7. The effect of phosphorus rate on on weight of seeds per plant and100 seeds.

Similarly, the highest weight of 100 seeds obtained by the application of $69 \mathrm{~kg} \mathrm{ha}^{-1} \mathrm{P}_{2} \mathrm{O}_{5}(3.9 \mathrm{~g})$. However, the lowest weight of 100 seeds registered due to zero $P$ application rate (3.4 g) (Figure 7). These findings also correlated as in [30, 37] reports.

Grain yield

Individual effects of crop variety and $\mathrm{P}$ application rate were showed highly significant $(p<0.01)$ influence on crop grain yield, meanwhile their interaction effect significant at $p$ $<0.05$ level on the grain yield of mung bean. The highest grain yield (1.65 t/ha) and lowest yield (1.15 t/ha) were recorded due to the use NVL1 and Shewarobit mung bean variety, respectively (Figure 8). In the study conducted on four mung bean varieties viz., BINAmung-2, BINAmung-5, BARImung-2 and BARImung-5 for three years revealed that BINAmung-5 gave the highest grain yield than the other tested varieties because it produced greater number of pods per plant [46]. Moreover, improved mung bean varieties were gave more grain yield than the local variety [47].

The maximum grain yield of $1630 \mathrm{~kg} \mathrm{ha}^{-1}$ was obtained due to the application of $69 \mathrm{~kg} \mathrm{ha}^{-1} \mathrm{P}_{2} \mathrm{O}_{5}$, meanwhile the minimum yield of $1280 \mathrm{~kg} \mathrm{ha}^{-1}$ recorded on control treatment (Figure 9). This result shows that seed yield increased by the application $\mathrm{P}$ fertilizer since more branches per plant, pods per plant, seeds per pod and higher pod length resulted through the availability of $P$ nutrient.

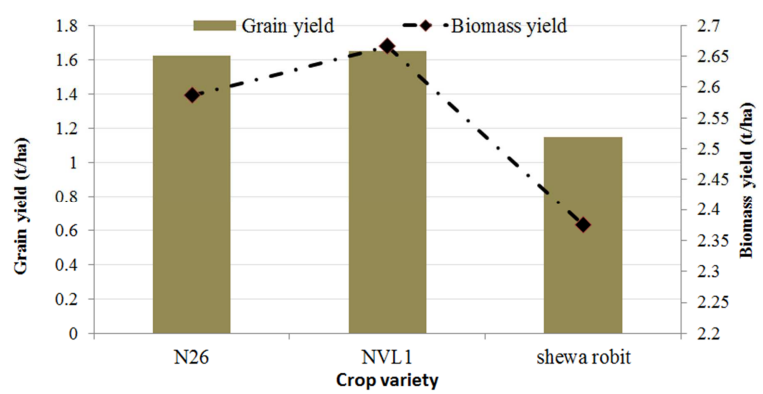

Figure 8. Grain and biomass yields were affected by the crop variety.
The present work findings are consistent as in [48, 49] reports also $\mathrm{P}$ application rates increased crop grain yield up to certain level. Moreover, $\mathrm{P}$ application enhance $\mathrm{N}$ uptake of mung bean [50, 51]. Besides, $\mathrm{P}$ application significantly increased the root biomass of mung bean [14]. Similarly, the experiment on the effects of $\mathrm{P}$ sources and rates on mung bean yield indicated that the crop showed more growth and yield responses due to the application of $60 \mathrm{~kg} \mathrm{ha}^{-1} \mathrm{P}_{2} \mathrm{O}_{5}$ [49].

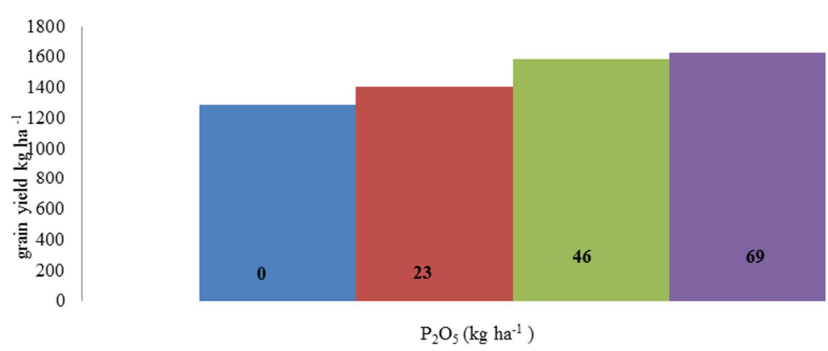

Figure 9. Grain yield of the crop influenced by the application of phosphorus.

On the other hand, the combined effect of crop variety and $P$ rate had significant $(\mathrm{p}<0.05)$ response on crop grain yield. The highest grain yield obtained due to the application of 69 $\mathrm{kg} \mathrm{ha}{ }^{-1} \mathrm{P}_{2} \mathrm{O}_{5}$ on NVL1 crop variety meanwhile the lowest grain yield was planting Shewarobit variety on zero $P$ application. The result of the study might be due to different response of three varieties of mung bean to phosphorus fertilizer. Similarly, the highest grain yield $\left(2.19 \mathrm{t} \mathrm{ha}^{-1}\right)$ was recorded from Binamoog-6 with application of $60 \mathrm{~kg} \mathrm{ha}^{-1}$ $\mathrm{P}_{2} \mathrm{O}_{5}$ followed by Binamoog-6 with $40 \mathrm{~kg} \mathrm{ha}^{-1} \mathrm{P}_{2} \mathrm{O}_{5}$ and the lowest grain yield $\left(0.81 \mathrm{t} \mathrm{ha}^{-1}\right)$ was recorded from BARI Mung-6 without application of phosphorus [52].

Table 3. Mean comparisons of seed yield due to interaction of crop variety and $P$ application rate.

\begin{tabular}{llll}
\hline \multirow{2}{*}{$\mathbf{P}_{2} \mathbf{O}_{\mathbf{5}} \mathbf{~ k g} / \mathbf{h a}$} & \multicolumn{4}{l}{ Mung bean variety } \\
\cline { 2 - 4 } & NVL1 & $\mathbf{N 2 6}$ & Shewarobit \\
\hline 0 & $1.51^{\mathrm{bc}}$ & $1.50^{\mathrm{c}}$ & $8.80^{\mathrm{f}}$ \\
23 & $1.60^{\mathrm{b}}$ & $1.58^{\mathrm{b}}$ & $1.04^{\mathrm{e}}$ \\
46 & $1.75^{\mathrm{a}}$ & $1.70^{\mathrm{a}}$ & $1.31^{\mathrm{d}}$ \\
69 & $1.76^{\mathrm{a}}$ & $1.76^{\mathrm{a}}$ & $1.36^{\mathrm{d}}$ \\
\hline
\end{tabular}

Means with the same letter are insignificant at $\mathrm{p}<0.05$.

\subsubsection{Biomass Yield}

Mung bean biomass yield significantly influenced by main effects of the crop variety and $\mathrm{P}$ application rate but nonsignificantly to their interaction effect. The highest crop biomass of $7.93 \mathrm{t} /$ ha was recorded on NVL 1 crop variety meanwhile the lowest $7.07 \mathrm{t} / \mathrm{ha}$ biomass obtained by Shewarobit crop variety (Figure 8 ). It might be due to the maximum plant height, higher number of branches per plant and number of pods per plant that contributed to higher straw yield. The straw yield varied due to variety conduct an experiment and SML 668 had the highest straw yield (4207 $\mathrm{kg} \mathrm{ha}^{-1}$ ) [37].

The highest biomass yield of $7.72 \mathrm{t} / \mathrm{ha}$ was registered on the highest $\mathrm{P}$ application rate since the crop growth and yield enhanced by the application of P nutrient (Figure 10). It was 
markedly observed that increase in the rate of phosphorus increased biomass yield and reached the maximum further increase of phosphorus did not increase the seed yield. Similarly, $60 \mathrm{~kg} / \mathrm{ha} \mathrm{P}$ application increased crop straw and grain yield of mung bean Meanwhile, the lowest biomass (7.12 t/ha) recorded on the control treatment [53].

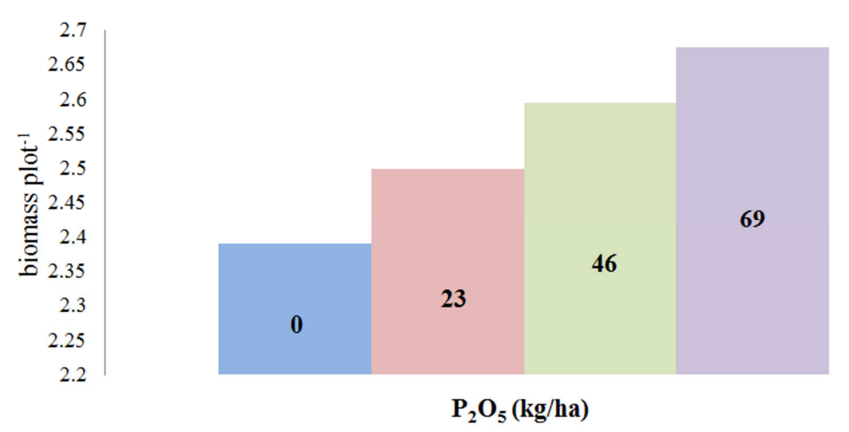

Figure 10. Biomass yield influenced by phosphorus rate.

\subsubsection{Harvest Index}

The individual effects of crop variety and $\mathrm{P}$ application rate have showed significant response to crop harvest index. However, the combined effect of crop variety and $P$ application not significantly affect the harvest index of mung bean. The maximum harvest index of $26.6 \%$ was observed on NVL 1 mung bean while the minimum index of $21.7 \%$ was recorded due to Shewarobit variety (Figure 11). Thus, improved variety of mung bean gave more grain yield as compared to local cultivar. The improved variety has more number of branches per plant, more number of pods per plant and seeds per pod longer pods contributed to the difference between improved varieties with local one under present experimental situation. These findings are also supported by [37] report.

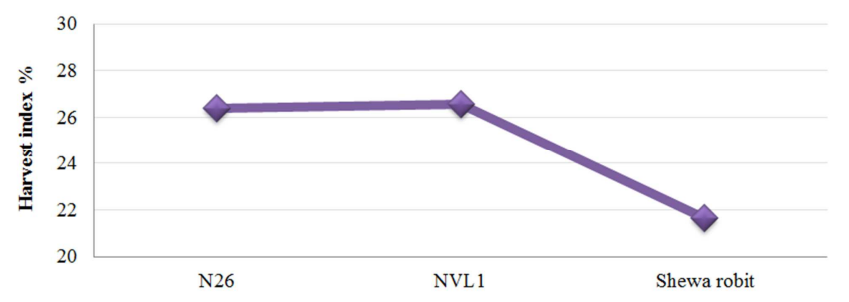

Figure 11. Individual effect of crop variety on harvest index.

Similarly, the maximum harvest index of (26.5\%) was recorded with application of $69 \mathrm{~kg} \mathrm{ha}^{-1} \mathrm{P}_{2} \mathrm{O}_{5}$ while the minimum index $(23.1 \%)$ was obtained at the control treatment. The application of phosphorus rates $(\mathrm{X})$ linearly increased the response harvest index of the crop $(y)(y=1.089 x+22.15$, at $\mathrm{R}^{2}=0.99$ ) (Figure 12). In line with this, $40 \mathrm{~kg} \mathrm{ha}^{-1} \mathrm{P}$ application increased number of seeds pod ${ }^{-1}$, seed yield per plant and crop grain yield response [44].

Hence, therefore the above findings on mung bean growth and yield highly affected with genetic makeup of the crop (variety) and $\mathrm{P}$ application rate. Accordingly, planting of mung bean NVL1 and N26 varieties is more promising than Shewarobit (local) variety. Similarly, high application rate of
$\mathrm{P}$ fertilizer has great impact to improve the grain and biomass yield of the crop. Finally, the combined use of N26 variety and $69 \mathrm{~kg} \mathrm{ha}^{-1} \mathrm{P}_{2} \mathrm{O}_{5}$ was found the most suitable management to increase mung bean yield in the study area.

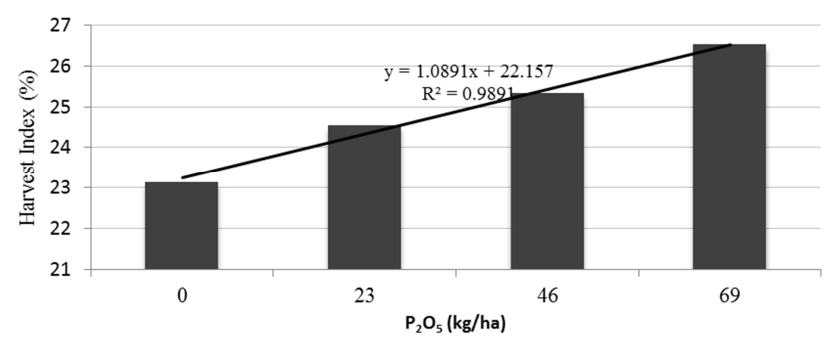

Figure 12. Effect of phosphorus application on harvest index of mung bean.

\subsection{Correlation Analysis}

The correlation analyses among the crop parameters were significant. However, plant height and stand count nonsignificantly related to most parameters of crop. Plant height significantly $(\mathrm{p}<0.05)$ and positively $\left(\mathrm{r}=0.38^{*}\right)$ correlated with biomass yield. Grain yield has strong correlation with number of pod per plant $\left(\mathrm{r}=0.75^{* *}\right)$, number of seed per pod $\left(\mathrm{r}=0.78^{* *}\right)$ and seed weight $\left(\mathrm{r}=0.91^{* *}\right)$. Number of pods per plant has highly significant correlation with number of seeds per pod $\left(\mathrm{r}=0.78^{* *}\right)$, seeds weight $(\mathrm{r}=0.54 * *)$, grain yield $\left(\mathrm{r}=0.76^{* *}\right)$, biomass yield $\left(\mathrm{r}=0.65^{* *}\right)$, and harvest index $\left(\mathrm{r}=0.63^{* *}\right)$. The same to this number of seeds per pod has higher correlation with seed weight $\left(\mathrm{r}=0.56^{* *}\right)$, grain yield $\left(\mathrm{r}=0.78^{* *}\right)$, biomass yield $\left(\mathrm{r}=0.80^{* *}\right)$, and harvest index $\left(\mathrm{r}=0.79^{* *}\right)$. Seed weight strongly related to grain yield $\mathrm{r}=0.8^{* *}$ and harvest index $0.78^{* *}$ but not correlated with plant height. As the result shows harvest index has strongly correlated with number of pod per plant $(\mathrm{r}=0.62 * *)$, number of seed per pod $\left(\mathrm{r}=0.79^{* *}\right)$, seed weight $\left(\mathrm{r}=0.77^{* *}\right)$, yield $\left(\mathrm{r}=0.85^{* *}\right)$ and biomass yield $\left(\mathrm{r}=0.70^{* *}\right)$ but not correlate with stand count and plant height. Biomass yield has highly significant correlation with number of pod per plant, number of seed per pod, and grain yield but not correlate with stand count. Finally, most parameters of the crop significantly and positively correlated with harvest index and grain yield.

\subsection{Economic Analysis}

The economic analysis results showed that the maximum net benefit $\left(23,623.95\right.$ birr ha $\left.^{-1}\right)$ with an acceptable MRR $(224.2 \%)$ was obtained from phosphorus fertilizer application of $46 \mathrm{~kg} \mathrm{ha}^{-1}$ for mung bean NVL 1 variety. This treatment resulted in a net benefit advantage of Birr 2,524.28 ha $\mathrm{her}^{-1}$ over the control treatment. The second highest net benefit (Birr 23,244.68 ha ${ }^{-1}$ ) with an acceptable MRR (127.9\%) for NVL 1 variety was obtained from mineral phosphorus fertilizer application of $69 \mathrm{~kg} \mathrm{ha}^{-1} \mathrm{P}_{2} \mathrm{O}_{5}$ this result is in par with the maximum result. In $\mathrm{N} 26$, variety the maximum net benefit (Birr 23,320.08 ha-1) with an acceptable MRR was obtained from $\mathrm{P}$ fertilizer at $69 \mathrm{~kg} \mathrm{ha}^{-1} \mathrm{P}_{2} \mathrm{O}_{5}$. This resulted in a net benefit advantage of 2,848.55 birr over the control treatments. The second highest net benefit $\left(22,955.26\right.$ birr ha $\left.^{-1}\right)$ with an 
acceptable MRR for N26 variety was obtained from mineral Phosphorus fertilizer application of $46 \mathrm{~kg} \mathrm{ha}^{-1} \mathrm{P}_{2} \mathrm{O}_{5}$. For Shewarobit variety the maximum net benefit $(17,283.42$ birr $\mathrm{ha}^{-1}$ ), with an acceptable MRR was obtained from the application of $69 \mathrm{~kg} \mathrm{ha}^{-1} \mathrm{P}_{2} \mathrm{O}_{5}$. This has resulted in a net benefit advantage of 5,542.92 birr over the control fertilizer application. The second highest net benefit $\left(17,109.6\right.$ birr ha $\left.^{-1}\right)$ with an acceptable MRR for Shewarobit variety was obtained from mineral Phosphorus fertilizer application of $46 \mathrm{~kg} \mathrm{ha}^{-1}$ $\mathrm{P}_{2} \mathrm{O}_{5}$ (Table 4).

Increase in output will raise profit as long as the marginal rate of return is higher than the minimum rate of return [22]. The analysis data show application rates of $46 \mathrm{~kg} \mathrm{P} \mathrm{ha}^{-1}$ for variety NVL1, and $69 \mathrm{~kg}$ P for N26 and Shewarobit varieties were economically feasible. The marginal rates of return at the phosphorus application rates of 23,46 , and $69 \mathrm{~kg} \mathrm{ha}^{-1} \mathrm{P}$ were greater than $150 \%$ for all variety, probably it is economical to apply as much as $69 \mathrm{~kg} \mathrm{ha}^{-1} \mathrm{P}$ for those varieties. Other treatments were eliminated by dominance analysis [22] since the net benefit obtained decreased as the cost increased.

Table 4. Economic analysis for effect of phosphorus fertilizer on three mung bean varieties.

\begin{tabular}{|c|c|c|c|c|c|c|c|}
\hline Variety & Pkg ha ${ }^{-1}$ & Average yield $\left(\mathrm{kg} \mathrm{ha}^{-1}\right)$ & Adjusted yield $\left(\mathrm{kg} \mathrm{ha}^{-1}\right)$ & Gross benefit (birr ha ${ }^{-1}$ ) & TVC (birr ha ${ }^{-1}$ ) & NB (birr ha ${ }^{-1}$ ) & MRR\% \\
\hline \multirow{4}{*}{ N26 } & 0 & 1463.67 & 1317.31 & 22229.61 & 1758.076 & 20471.53 & 0 \\
\hline & 23 & 1577.00 & 1419.3 & 23950.69 & 2320.316 & 21630.37 & 206.1117 \\
\hline & 46 & 1701.33 & 1531.2 & 25839 & 2883.744 & 22955.26 & 220.6448 \\
\hline & 69 & 1762.00 & 1585.8 & 26760.38 & 3440.296 & 23320.08 & 169.3328 \\
\hline \multirow{4}{*}{ NVL1 } & 0 & 1505.33 & 1354.8 & 22862.25 & 1762.576 & 21099.67 & 0 \\
\hline & 23 & 1597.67 & 1437.91 & 24264.73 & 2322.548 & 21942.18 & 150.4553 \\
\hline & 46 & 1745.67 & 1571.11 & 26512.48 & 2888.532 & 23623.95 & 224.1893 \\
\hline & 69 & 1757.00 & 1581.3 & 26684.44 & 3439.756 & 23244.68 & 127.8936 \\
\hline \multirow{4}{*}{$\begin{array}{l}\text { Shewar } \\
\text { obit }\end{array}$} & 0 & 884.67 & 796.21 & 13436.04 & 1695.544 & 11740.5 & 0 \\
\hline & 23 & 1037.67 & 933.91 & 15759.73 & 2262.068 & 13497.66 & 310.1658 \\
\hline & 46 & 1313.67 & 1182.31 & 19951.48 & 2841.876 & 17109.6 & 468.3726 \\
\hline & 69 & 1361.67 & 1225.51 & 20680.48 & 3397.06 & 17283.42 & 325.7637 \\
\hline
\end{tabular}

TVC=Total variable cost; NB=Net benefit; MRR=Marginal rate of return. Sale price of mung bean grain ETB $25 \mathrm{~kg}^{-1}$; cost of weeding is $1000 \mathrm{ETB}$ ha ${ }^{-1}$; Cost of harvesting including threshing and winnowing ETB 80 per $100 \mathrm{~kg}$; Packing and material cost Birr 7 per $100 \mathrm{~kg}$ and transportation Birr 5 per $100 \mathrm{~kg}$.

Phosphorus fertilizer application for all the three varieties gave positive benefit over the control treatment. This means a very high increase in farmers' income with a simple improvement in crop nutrient management strategy. The same to this result, many studies reported that the income from fertilizer is much greater as compared to the yield from zero fertilizer rates. Finally, application of phosphorus at 46 $\mathrm{kg} \mathrm{ha}^{-1}$ rate gave economically optimum grain yields for variety NVL 1, whereas application of phosphorus at the rate of $69 \mathrm{~kg} \mathrm{P} \mathrm{ha}{ }^{-1}$ that led to the production of optimum grain yield for varieties N26 and Shewarobit (local).

\section{Summary and Conclusion}

The response of different mung bean varieties to $\mathrm{P}$ application rate study was conducted in Ambasel District in 2016 main season. The factorial combination of three mung bean varieties (N26, NVL1, and Shewarobit) and four $\mathrm{P}$ levels $\left(0,23,46\right.$ and $\left.69 \mathrm{~kg} / \mathrm{ha} \mathrm{P}_{2} \mathrm{O}_{5}\right)$ treatments were replicated three times. The experiment was laid out in a randomized complete block design. The experimental plot size was $2.5 \mathrm{~m} \mathrm{x} 2 \mathrm{~m}$. The predetermined rate of phosphorus fertilizer as of TSP was applied in band during crop planting. Starter N fertilizer $11.5 \mathrm{~kg} /$ ha also applied for all plots at crop planting. The crops planted on intra and inter row spacing of 10 and $40 \mathrm{~cm}$, respectively. All recommended cultural practices adopted for mung bean production were implemented in the experiment. Crop growth and yield data collected and their ANOVA and mean separation analyzed with SAS software.
Stand count at emergence and harvest revealed no significant variation due to the main effect of the variety. Plant height was significantly influenced by individual effects of $\mathrm{P}$ application rate and mung bean variety. The longest plant height were recorded by $\mathrm{N} 26$ variety and $69 \mathrm{~kg}$ ha $^{-1} \quad \mathrm{P}_{2} \mathrm{O}_{5}$ appliedtreatments meanwhile shortest height observed on Shewarobit variety and zero $\mathrm{P}$ rate treatments. Number of pods per plant was significantly increased by variety and phosphorus fertilization. The highest number of pods per plant was obtained from NVL1 while the lowest number of pods obtained by Shewarobit (local) variety. Similarly, highest number of pods per plant registered due to the application of $46 \mathrm{~kg} \mathrm{ha}^{-1} \mathrm{P}_{2} \mathrm{O}_{5}$ meanwhile the lowest registered from the control treatment. The interaction of phosphorus and variety gave higher number of pods per plant, the highest pod per plant registered by mung bean NVL1 variety which grown on 46 and $69 \mathrm{~kg} \mathrm{ha}^{-1} \mathrm{P}_{2} \mathrm{O}_{5}$ fertilizer 34.56 and 34.26, respectively. However, the lowest pod per plant registered from Shewarobit variety that grown on zero phosphorus rate.

Variety and phosphorus fertilizer significantly influenced the number of seeds pod $^{-1}$. Maximum number of seeds per pod (8.9) was obtained from N26 while the lowest of seeds per pod (7.9) was found on Shewarobit variety. Application of $69 \mathrm{~kg} \mathrm{ha}^{-1} \mathrm{P}_{2} \mathrm{O}_{5}$ gave maximum number of seeds per pod (9.1) but zero $\mathrm{P}$ applied plot resulted minimum number of seeds per pod. Based on the interaction the maximum number of seeds per pod (9.35 and 9.20) was obtained from N26 variety grown at 69 and $46 \mathrm{~kg} \mathrm{ha}^{-1} \mathrm{P}_{2} \mathrm{O}_{5}$, respectively. Maximum dry seeds weight per plant $(10.6 \mathrm{~g})$ was recorded 
on mung bean N 26 variety but the minimum dry seeds weight per plant $(7.2 \mathrm{~g})$ occurred on Shewarobit variety. Similarly, maximum application rate of $\mathrm{P}$ fertilizer gave maximum dry seeds weight per plant $(10.4 \mathrm{~g})$ while zero $\mathrm{P}$ responded the minimum weight of dry seeds per plant $(7.9 \mathrm{~g})$.

Seed yield and biomass yield were significantly influenced by Individual effects of crop variety and phosphorus fertilization. The maximum grain $\left(1.7 \mathrm{t} \mathrm{ha}^{-1}\right)$ and biomass (7.93 $\mathrm{t} \mathrm{ha}^{-1}$ ) yields were obtained by planting mung bean NVL variety while minimum grain $\left(1.1 \mathrm{t} \mathrm{ha}^{-1}\right)$ and biomass $\left(7.07 \mathrm{t} \mathrm{ha}^{-1}\right)$ yields were recorded by Shewarobit mung bean. Similarly, maximum grain $\left(1.6 \mathrm{tha}^{-1}\right)$ and biomass $(7.72 \mathrm{t} \mathrm{ha}$ ${ }^{1}$ ) yields were found by application of $69 \mathrm{~kg} \mathrm{ha}^{-1} \mathrm{P}_{2} \mathrm{O}_{5}$, meanwhile minimum grain $\left(1.3 \mathrm{t} \mathrm{ha}^{-1}\right)$ and biomass $(6.25 \mathrm{t}$ $\mathrm{ha}^{-1}$ ) yields were recorded on control $\mathrm{P}$ application. The minimum is from controlled Shewarobit variety. The maximum biomass yield $\left(8.3 \mathrm{t} \mathrm{ha}^{-1}\right)$ was obtained from NVL1 grown at $69 \mathrm{~kg} \mathrm{ha}^{-1} \mathrm{P}_{2} \mathrm{O}_{5}$ but the minimum biomass of $6.25 \mathrm{t} \mathrm{ha}^{-1}$ was recorded by mung bean Shewarobit.

The highest $(26.6 \%)$ and the lowest $(21.7 \%)$ harvest index were obtained fromNVL 1 and Shewarobit, respectively. Application of $69 \mathrm{~kg} \mathrm{ha}^{-1} \mathrm{P}_{2} \mathrm{O}_{5}$ produced the highest harvest index $(26.5 \%)$ and the lowest harvest index (23.1\%) was found at control. It can be concluded that NVL1 performed better than N26, and Shewarobit (local) in respect of productivity. Application of phosphorus up to $46 \mathrm{~kg} \mathrm{P}_{2} \mathrm{O}_{5} \mathrm{ha}^{-1}$ increased the seed yield very fast further higher dose of phosphorus increases seed yield slowly. N26 grown with 69 $\mathrm{kg} \mathrm{ha}^{-1} \mathrm{P}_{2} \mathrm{O}_{5}$ emerged as the promising one to increase the yield of the crop as compared to other treatment combinations.

The post harvested soil analysis result indicated that the improved variety (N 26) recorded highest residual soil $\mathrm{N}$ $(0.2 \%)$ but the post harvest soil of local cultivar (Shewarobet) with lower residual soil $\mathrm{N}(0.18)$. Thus, improved mung bean variety removed lower $\mathrm{N}$ nutrient as compared to local variety, it might be due to more fixation capacity of an improved varieties. Maximum residual organic matter was recorded on minimum $\mathrm{P}$ applied treatment, however minimum organic carbon observed on maximum $\mathrm{P}$ applied treatments. It might be due to the applied $\mathrm{P}$ enhance decomposition of organic matter.

This conclusion has been made based on the results of the study that was conducted in one season only. Therefore further empirical studies required to put forward comprehensive conclusion due to climatic and soil variations of the country.

\section{References}

[1] Ketinge, J., Easdown, W., Yang, A., Chadha, R. and Shanmugasundaram, M. S. Euphytica, 2011, 180: pp 129-141.

[2] FAO. The State of Food Insecurity in the World: when people must live with fear, hunger and starvation. FAO. Rome. 2004, ISBN 92-5-104815-0.

[3] Yadi R. Role of zinc fertilizer on grain yield and some qualities parameters in Iranian rice genotypes. Annals of Biological Research 3 (9): 2012, 4519-4527.

[4] Imran. Effect of germination on proximate composition of two maize cultivars. J Bio Agric Health Care, 2015, 5 (3): 123-128.

[5] Imran, Khan AA, Inam I, Ahmad F. Yield, and yield attributes of mung bean (Vigna radiate L) cultivars as affected by phosphorous levels under different tillage systems. Cogent Food \& Agriculture. 2016, 2: 1151982.

[6] Muhammad, A. N., Rashid, A. and Ahmad, M. S. Effect of seed inoculation and different fertilizer levels on the growth and yield of mung bean (Vigna radiata L.) J. Agronomy, 2004, 3: 40-42.

[7] Anjum, M. S., Z. I. Ahmed and C. A. Rauf. Effect of Rhizobium Inoculation and Nitrogen Fertilizer on Yield and Yield Components of Mung bean International Journal of Agriculture \& Biology, 2006, 8 (2) pp 238-240.

[8] Hossain M. A. and A. Hamid. Influence of N and P fertilizer application on root growth, leaf photosynthesis and yield performance of groundnut. Bangladesh J. Agri. Res. 2007, 32 (3): pp 369-374.

[9] Raboy V., 2003. Molecules of interest: myo-inositol ${ }^{-1}, 2,3,4$, 5, 6-hexakisphosphate. Phytochem. 64: pp 1033-1043.

[10] Peter, H. G. and Vance, C. P. 2003. Legumes: importance and constraints to greater use. Plant Physiol. 131: 872-877.

[11] Khan, M. U., M. Qasim and M. Jamil. Effect of Zn on Starch ] Content of Paddy and Zinc Content of soil, leaf and root of Rice grown in calcareous soils. Int. J. Agric. Biol., 2004, 6: pp 1132-1135.

[12] Shah S. K. H., M. Aslam, P. Khan, M. Y. Memon, M. Imtiaz, S Siddiqui and Nizamuddin. Effect of different methods and rates of phosphorus application in mung bean. Soil \& Environ. 2006, 25 (1): 55-58.

[13] Singh, M.; Sekhon, H. S. and Singh, J. Growth and nutrition characteristics of mung bean (Vigna radiata L.) genotypes in response to phosphorus application. Crop Res. Hisar. 2005. 29 (1): 101-105.

[14] Amanullah and B. A. Stewart. Dry matter partitioning, growth analysis and water use efficiency response of oats (Avena sativa L.) to excessive nitrogen and phosphorus application. Journal Agricultural Science Technology. 2013. 15: 479-489.

[15] Jackson, M. Soil Chemical Analysis. Prentice-Hall, Inc., Engle Wood Cliffs, pp. 183-204, New Jersey, USA. 1958.

[16] Walkley, A. and Black, C. An examination of different methods for determining soil organic matter and the proposed modification by the chromic acid titration method. Soil Science, 1934. 37: pp 29-38.

[17] Olsen, S. R. Cole, C. V. Watanabe, F. S. and Dean, L. A. 1954. Estimation of Available Phosphorus in Soils by Extraction with Sodium Bicarbonate. USDA Circular 939: 1-19.

[18] Murphy, J. and Riley, J. Amodified single solution method for determination of phosphate in natural waters, Analytical Chimica Act, 1962, 27: 31-36.

[19] Toth, S. J. and Prince, A. L. Estimation of cation exchange capacity and exchangeable $\mathrm{Ca}, \mathrm{K}$ and $\mathrm{Na}$ contents of soils by flame photometric techniques. Soil Science, 1949, 67: 439-445. 
[20] Gomez, K. and Gomez, A. Statistical Procedure for Agricultural Research, Second Edition. A Wiley Inter-Science Publication, New York, USA. 1984.

[21] SAS Institute Inc. SAS User's Guide, Statistics v. 9.1 (ed.), SAS Inst. Cary, NC, USA. 2002.

[22] CIMMYT (Centro Internacional de Mejoramiento de Maíz y Trigo). International Maize and Wheat Improvement Center, from Agronomic Data to farmer Recommendations: An Economics training manual. 1988.

[23] Tisdale, S. L., J. D. Nelson, Beaton and J. L. Havlin. Soil Fertility and Fertilizer. ( $7^{\text {th }}$ Eds.) Prentice-Hall of India, New Delhi. 2002.

[24] Landon, J. R. 1991. Booker Tropical Soil Manual: A handbook for Soil Survey and Agricultural land evaluation in the Tropics and Sub-tropics. Longman Scientific and Technical, Essex, New York.

[25] Emsley, J. The Shocking History of Phosphorus. London: Macmillan. 2000.

[26] Bhuiyan. M. M. H., M. M. Rehman, F. Afroze, G. N. C. Sutradhar and M. S. I. Bhuiyan, Effect of phosphorus, molybdenum and rhizobium inoculation on yield and yield attributes of mungbean. Journal of Soil Nature. 2008. 2 (2): pp 25-30.

[27] Iqbal. S., H. Z. Khan. And H. Shaheen, Growth and yield responses of mung bean (Vigna radiatal.) to different levels of phosphorus application under different tillage systems. Int. J. Agric. Sci. 2012. Vol. 4, No. 1 pp 22-27.

[28] Lange, S., Peer Schmidt, and Tom Nilges. "Phosphorus: An Easy Access to higher yields of pulses". Inorg. Chem. 2007. 46: 4028 .

[29] Maqsood, M., M. Hassan, M. I. Hussain \& M. T. Mahmood. Effect of different levels of phosphorus on agronomic traits of two mash bean genotypes (VignamungoL.). Pale. J. Agri. Set. 2001, 38 (1-2): 81-83.

[30] Malik, M. A., S. Hussain, E. A. Warraich, A. Habib and S. Ullah. Effect of Seed inoculation and phosphorus application on growth, seed yield and quality of mung bean (Vigna radiate L.) CV. NM-98. Int. J. Agric. \& Biol., 2002.4 (4): 515-516.

[31] Norman M. J. T. Response of Vigna radiata to nitrogen and phosphate fertilizer. Australian J. Exp. Agric. and Animal Husbandry, 2006, 2 (4): 27-34.

[32] Aguilar E. A. and Villarea R. L. Evaluation of the yield stability of promising mung bean selection under different growing environments. The Philippines Agric. 1989. 7 2: 255269.

[33] Thakuria, K. and Shaharia, P. Response of green gram genotypes to plant density and phosphorus levels in summer. Indian J. Agron. 1990. 35 (4): 431-432.

[34] Abbasi M., Majeed A, sadia, A, Khan, SR. Application of Bbrady rhizobium japonicum and phosphorous fertilization improved growth, yield and nodulation of soybean in the subhumid Hilly region of Azad Jammu and Kashmir, Pakistan. Plant Prod Sci. 2008, 11 (3): pp 368-376.

[35] Chaudhary, M. I., J. Adu-Gyamfi, H. Saneoka, N. T. Nguyen, R. Suwa, S. Kanai, H. El-Shemy, Bishnoi U. R., G. Kaur, M. H. Khan. Calcium, phosphorus, and harvest stages effects soybean seed production and quality. Journal of Plant Nutrition, 2007, 30: pp 2119-2127.

[36] Amanullah, Majidullah and Imran Khan. Phenomorphological traits of mungbean as influenced by phosphorous and tillage under irrigated and un-irrigated conditions. Pure Applied Biology, 2014, 3 (2): 55-59.

[37] Singh, G.; Sekhon, H. S.; Poonam Sharma, P. and Bains, T. S. Response of mung bean varieties to plant populations in summer season. Indian J. Food Legumes. 2007, 20 (1): 115116.

[38] Soni, K. C. and Gupta, S. C. Effect of irrigation schedule and phosphorus on yield, quality and water-use efficiency of summer mung bean (Phaseolus radiatus). Indian J. Agron. 1999, 44 (1): 130-133.

[39] Rahman, M. M., Bhuiyan, M. H., Sutradhar, G. N. C., M. M. and Paul, A. K. Effect of phosphorus, molybdenum and rhizobium inoculation on yield and yield attributes of mung bean, Int. J. Sustain. Crop Prod., 2008, Vol. 3 pp. 26-33.

[40] Kumar, S.; Singh, R. C. and Kadian, V. S. Response of mung bean genotypes to phosphorus application. Indian J. Pulses Res. 2003. 16 (1): 65-66.

[41] Mandal, R. and Sikder, B. C. Effect of nitrogen and phosphorus on growth and yield of mung bean grown in saline soil of Khulna, Bangladesh. J. Phytological Res. 1999, 12 (12): $85-88$.

[42] Mitra, S., S. K. Rhattacharya, M. Datta and S. Banik, Effect of variety, rock phosphate and phosphate solubilizing bacteria on growth and yield of green gram in acid soils of Tripura. Environmental Economics. 1999, 17: pp 926-930.

[43] Ahmad, I.; Alamgir, A. and. Tarar, F. S. A. Yield and yield component response of mung bean to different $\mathrm{P}$ levels and row spacing. Indian journal Biological Science, 2005, 2 (1): 27-31.

[44] Sardar, M. S. U. Influence of plant density and phosphorus and inoculation on the growth and yield of mung bean (cv. BINAmung-2). An M. S. Thesis in Agronomy, BAU, Mymensingh, 2002, pp 52.

[45] Manivannan, N. Genetic variability for seed yield and its components of mung bean (Vigna radiata (L) Wilczek). Agril. Sci. Digest, Karnal. 1999. 19 (2): 96-98.

[46] Mondal, M. M. A.; Dutta, R. K. and Islam, M. A. Yield performance of some elite mung bean mutants in the northern region of Bangladesh. Bangladesh J. Nuclear Agric. 2004. 19: 32-35.

[47] Nayak, B. C. and Patra, A. K. Response of mung bean (Vigna radiata) cultivars to dates of sowing during winter. Indian $J$. Agric. Sci., 2000, 70 (5): 324- 322.

[48] Verma, L. K, and Singh, R. P. Effect of phosphorus on nitrogen fixing potential of rhizobiurn and their response on yield of mung bean (Vigna radiata), Department of Soil Science, N. D. University of Agriculture 54 and Technology, Kumarganj, Faizabad, U. P., India. Asian. I. Soil Sci. 2008, 3 (2): $310-312$.

[49] Singh, B.; Singh, C. P. and Parihar, S. S. Growth and yield enhancement of mung bean (Vigna radiata L.) by sources and levels of phosphorus and phosphate solubilizing microbes. Annals Agric. Res., 2006, 27 (3): 210-212. 
[50] Gowda, D., and A. M. Gowda. Effect of Rhizobium and fertilizers on biometric parameters of green gram. Crop Res. Hisar., 1978, 22: 367-36.

[51] Beg, M. Z., S. Ahmad and D. K. Srivastava. Effect of phosphorus on yield and grain protein content of two important Indian pulses. Indian. Journal. L. Sci., 2013, 2 (2): pp 43-48.
[52] Parvez, M. T. S. K. Paul and M. A. R. Sarkar. Yield and yield contributing characters of mung bean as affected by variety and level of phosphorus Journal of Agro forestry Environment, 2013, 7 (1): 115-118.

[53] Yadav, B. L. and Jakhar, S. R. Effect of tillage and phosphorus fertilization on yield and water expense efficiency of rain fed mung bean. J. Indian Soc. Soil Sci., 2001, 49 (1): 193-194. 